\title{
Consent and Third-Party Coercion ${ }^{1}$
}

\author{
Mollie Gerver
}

\begin{abstract}
:
It is commonly claimed that, when $X$ coerces $Y$ into consenting to $Z \varphi$-ing, $Y^{\prime}$ s consent is invalid, and $\mathrm{Z}$ is only permitted to $\varphi$ if this reduces harm or increases optionality for Y. This article demonstrates that Y's consent in such cases is valid if $Y$ is choosing between options that include all those $Z$ has a duty to offer $Y$, and no autonomy-reducing options $Z$ has a duty to not offer $Y$. When these conditions are met, $Z$ acts permissibly in $\varphi$-ing even if $\varphi$-ing does not reduce harm for $Y$ or increase $Y^{\prime}$ s optionality.
\end{abstract}

\footnotetext{
${ }^{1}$ For helpful comments, a special thanks to James Christensen, Paul Bou-Habib, Michelle Dempsey, Tom Dougherty, Benedict Elliott Smith, Joe Horton, Kasim Khorasanee, Quill Kukla, Hallie Liberto, and Victor Tadros. I also thank two anonymous reviewers and audiences at University College London and the University of Warwick. A special thanks to Kai Spiekermann for earlier discussions on the topic of thirdparty coercion amongst refugees and aid workers.
} 
In March 1991 civil war broke out in Sierra Leone, eventually reaching the home of a young woman named Aminata. Within a year, Aminata was captured and brought to a Revolutionary United Front (RUF) military base, where she was threatened with rape from an RUF soldier. She knew the threats would subside if she were married, as soldiers were less likely to rape married women on the base. She spoke with a man she knew and consented to marry him shortly after. ${ }^{1}$

The above case raises a question: was Aminata's consent valid, given that it was the result of a soldier's threat?

Many would claim it was not: consent is always invalid when the result of wrongful coercion, including coercion from a third party. ${ }^{2}$

More specifically, many make two claims. The first is that valid consent is sufficient to give permission to the consent-seeker. ${ }^{3}$ By this I mean that consent dissolves a duty owed by the consent-seeker to the consent-giver. ${ }^{4}$ If a woman validly consents to sex with her partner, the consent dissolves her partner's moral duty to not have sex with her. ${ }^{5}$ The second claim is that a central function of valid consent is to give individuals the autonomous control to dissolve another agent's duty, ${ }^{6}$ and such control is lacking when consent is the result of a consent-seeker's wrongful threat. ${ }^{7}$ If a woman consents to sex only because her partner threatens to injure her if she does not, her consent is invalid because she is denied control over whether her partner maintains a duty to not have sex with her.

If a central function of valid consent is to give individuals control to dissolve others' duties, and this explains why direct threats from consent-seekers are sufficient to undermine valid consent, it seems threats from third parties are sufficient to undermine valid consent as well. 
If they do, this has a number of potential further implications. One potential implication is that those acting on coerced consent always act impermissibly. ${ }^{8}$ The man that Aminata married acted impermissibly in marrying her, given that she was the victim of a wrongful threat. Alternatively, it may be that those acting on coerced consent cannot rely on consent alone to obtain permission for their actions. They must also be certain that their actions reduce harm, or increase optionality, ${ }^{9}$ or are the only actions which can help the consent-giver avoid the fulfilment of the coercer's threat. ${ }^{10}$ For example, the man Aminata married must have ensured that, in agreeing to marry her, he increased her options, or reduced the harm she faced, or was providing her the only option for avoiding rape.

In this article I reject the above claims, defending an alternative: when $\mathrm{X}$ coerces $\mathrm{Y}$ into consenting to $Z \varphi$-ing, $Z$ is permitted to act based on $Y^{\prime}$ 's consent if $Y$ is choosing between options that include all those Z has a duty to offer $Y$, and no autonomy-reducing options Z has a duty to not offer $Y$. When these conditions are met, $Z$ acts permissibly even if she does not reduce harm for $Y$, or increase $Y^{\prime}$ 's optionality, or provide the only option which helps $Y$ avoid the fulfilment of $X^{\prime}$ s threat. In Section 1 I demonstrate that these conditions are sufficient to validate consent, in Section 2 I respond to objections, and in Section 3 I demonstrate that third-party coercion is insufficient to invalidate consent. In Sections 4 and 5 I demonstrate that the theory I present is applicable to two more complex variants of third-party coercion: cases where $X$ threatens to harm $Y$ unless she merely gives permission to $Z \varphi$-ing, regardless of whether $Z$ actually $\varphi$-es, and cases where $X$ threatens to harm a third-party $W$ unless $Y$ consents to $Z \varphi$-ing.

\section{Sufficient Conditions for Permission with Third-Party Coercion}

In paradigmatic cases of third-party coercion, $X$ will harm $Y$ unless $Z \varphi$-es ${ }^{11}$, $Y$ consents to $Z \varphi$-ing solely to avoid being harmed by $X^{, 12}$ and $Z$ is aware of $X^{\prime} s$ threat of harm but not causally contributing to this threat of harm. ${ }^{13}$

Consider the following case: 
Asylum: A Darfuri man named David was threatened with arrest by the Sudanese government unless he left the country, which he could only do if someone smuggled him into Ethiopia. As a result, he consented to Ashoul smuggling him into Ethiopia. Ashoul worked for the UN, providing this service for free, and in no way causally contributed to the government's persecution which forced David to leave. Nor could she have helped him reach a country other than Ethiopia, or stopped the government's persecution without risking her own life and others' ${ }^{\prime 14}$

We ought to adopt the view that Ashoul had permission because of David's consent, rather than because helping him to cross the border reduced harm, increased his options, or was the only way to stop David being harmed by the government.

To defend this claim, I begin with the assumption that the function of valid consent is to enable individuals to autonomously dissolve others' duties. I adopt this assumption because it is plausible, widely held, ${ }^{15}$ and held in particular by proponents of the view that third-party coercion invalidates consent. ${ }^{16}$ Proponents hold that the function of consent is to give individuals the autonomy to dissolve others' duties, and if thirdparty coercion undermines this autonomy, third-party coercion undermines consent.

I shall also assume - consistent with proponents of the view I reject - that autonomy requires a certain level of optionality. Coercion can impact the number and quality of options a person has, which can impact the level of autonomy a person has. ${ }^{17}$ For example, a person with no options lacks autonomy entirely: David was not in this position as he could remain and face persecution if he chose..$^{18}$ Or a person may have every option they have a right to receive from all agents, providing a very high degree of autonomy: David was not in this position either as he was denied the option to be free from persecution from his government.

Alternatively, a person may be denied options they have a right to receive from some agents, but have (a) all options they have a right to receive from the consent-seeker, and (b) no autonomy-reducing options they have a right to not receive from the consent-seeker. In other words, they have the autonomy they have a right to receive from the consent-seeker. I call this "relative autonomy."19 David had relative 
autonomy from Ashoul. He had the option of crossing the border and, though he lacked the option to be free from persecution where he was, this was not an option he had a right to receive from Ashoul, as this would have risked her life and others'.

For consent-givers to receive all options they have a right to from a consent-seeker, their options must also include any to which they have a conditional right, contingent on other offers made by the consent-seeker. For example, while David may have no right to receive help from Ashoul, were it to be offered he may have a right to receive the assistance without paying an unreasonable fee. Were Ashoul only to offer David the option of paying a great deal of money for her help, money which only serves to enrich her, this might be impermissibly exploitative. To avoid impermissibly exploiting him she would need to either not offer any smuggling, or to also offer smuggling without this unjustified fee. ${ }^{20}$ Since David was offered free help, he received all options to which he had a conditional right.

As noted, to have relative autonomy consent-seekers must also receive no options they have a right to not receive, where the provision of the option itself reduces their autonomy. Imagine David's cousin offers to help him resettle to Canada or the United States on the condition that he has no alternative, and consequently Ashoul offers him safety in Ethiopia to spitefully prevent him reaching Canada or the United States. Ashoul's offer might be impermissible, given that her intention is to destroy two higher-quality options that David would prefer. In Asylum, David was given no such autonomy-reducing impermissible options.

If David was afforded as much autonomy as Ashoul had a duty to provide him, Ashoul did not wrong him by making the offer. If she did not wrong him in making the offer, it seems she did not wrong him by enacting the offer with his consent. If she did not wrong him in enacting the offer, it seems he successfully gave her permission to enact the offer. If the function of consent is to provide individuals the autonomy to give others permission, this level of autonomy is sufficient to fulfil the function of consent. 
Put another way, it is widely accepted that valid consent is not merely an act or mental state that protects autonomy, but an act or mental state that protects autonomy by enabling the consent-giver to change their relationship with the consent-seeker. ${ }^{21}$ Such a change in relationship is achieved when the consent-giver has sufficient autonomy to dissolve a duty of the consent-seeker. They have sufficient autonomy if the consentseeker provides all options she must provide, and no autonomy-reducing options she must not provide.

If consent-seekers can obtain valid consent in such cases, and valid consent implies permission, it follows that consent-seekers can obtain permission even if they do not help consent-givers experience less harm or increased optionality. This implication is intuitively appealing. Imagine multiple agents offer the same assistance, such that none individually increase the consent-giver's optionality. It seems each agent can still obtain the consent-giver's valid consent, and the theory of relative autonomy explains why: each independently provides the autonomy she has a duty to provide. Or consider an agent offering assistance that is just as harmful as no assistance: an aid worker might offer David potentially life-threatening smuggling, such that the risk of death in escaping is equal to the risk of death in remaining. This aid worker could obtain David's valid consent to escape persecution if she provided him as much autonomy as she had a duty to provide. ${ }^{22}$ We might even imagine a case where an agent neither decreases harm nor increases optionality, such as Ashoul providing the same option that others would if she did not, and the option of reaching Ethiopia is as risky as remaining. Relative autonomy can explain why David can give valid consent in such cases, and thus why he gave permission.

Moreover, if an agent provides as much autonomy as she has a duty to provide, she may obtain valid consent even if the assistance is neither the only nor best assistance for the consent-giver to avoid the fulfilment of the third party's threat. This, too, is intuitively appealing. The very best option for David avoiding the government's threat might be asylum in a far-away country, because in a near-by country David might be 
pursued by his government's invading military. If providing him this far-away option would cost the aid worker her life savings and free time, and so be non-obligatory, she could still obtain David's valid consent if she merely gave him the option of crossing the border.

In addition to increased optionality and harm avoidance not being necessary for permission under third-party coercion, they are also not sufficient. An agent may fail to obtain permission despite increasing optionality and reducing harm, even if increasing optionality and reducing harm to a greater degree than others who may obtain valid consent and permission for equivalent actions. For example, compare Ashoul to another aid worker with the duty to provide David four options: remaining in Sudan, helping him cross the border for free, resettlement in Brazil and resettlement in Australia. This second aid worker might have a duty to provide these options because she easily can, or because she has donations set aside to do so. If she instead provides only the first three options, she may increase his optionality and reduce harm compared to Ashoul, but nonetheless acts impermissibly and fails to obtain valid consent. This is because she fails to provide David the additional option - resettlement in Australia - which she has a duty to provide. In other words, we can determine if she obtains valid consent and acts permissibly based on the duties she has fulfilled, and not the absolute number of options, help, or autonomy she provides.

The above set of claims can be summarised as follows:

(a) Consent's function is to give agents the ability to autonomously dissolve others' duties.

(b) When $X$ will impermissibly harm $Y$ unless $Z \varphi$-es, then $Y$ has the ability to autonomously dissolve Z's duty to not $\varphi$ if $\mathrm{X}$ has "relative autonomy."

(c) Relative autonomy describes $Z$ 's provision to $Y$ of all options she has a duty to provide, and no autonomy-reducing options she has a duty to not provide.

(d) When $Y$ consents with relative autonomy, then $Z$ acts permissibly in $\varphi$-ing even if 
i. this does not reduce harm for $Y$,

ii. this does not increase Y's optionality, and

iii. this does not provide $Y$ the only or best way of avoiding $X^{\prime}$ 's harm.

(e) When $\mathrm{Y}$ consents without relative autonomy, then $\mathrm{Z}$ does not necessarily act permissibly in $\varphi$-ing even if

i. this reduces harm for $Y$,

ii. this increases Y's optionality, and

iii. this provides $\mathrm{Y}$ the only or best way of avoiding $\mathrm{X}^{\prime} \mathrm{s}$ harm.

\section{Four objections}

Some might reject the claim that consent's function is to enable agents to autonomously dissolve others' duties. Those who reject this claim might raise four objections to the argument above.

\subsection{Discretionary authority}

Some claim consent's function is to protect what Japa Pallikkathayil calls the "discretionary authority" an individual ought to have over certain domains. For example, an individual ought to have authority over their body or property, which is why they must voluntarily consent before others touch their body or take their property. An individual has not voluntarily consented if they are coerced by a third party. $^{23}$

Even if consent's function is to protect individuals' authority over certain domains, an individual's authority would not be protected if he were unable to give valid consent when faced with a third-party threat. If he were unable to give valid consent, he might face the fulfilment of the third party's threat, and this would undermine his authority over a range of domains in his life. David would face persecution from the government if he were unable to leave, which might entail imprisonment or death. If imprisonment or death undermine David's authority over his body and life, David has greater authority if he has the option of receiving help from Ashoul. 
Some might agree that David has greater authority if Ashoul helps him escape, but still insist that no valid consent took place because David lacks the discretionary authority he has a right to receive from all agents. Under this view, Ashoul can permissibly help him escape, because at least she can improve his authority over his life compared to no help, but David still never gave his valid consent.

Even if one accepts this view, it is consistent with my more substantive claim: $\mathrm{Y}$ can dissolve Z's duty to not $\varphi$ even if he is coerced by $Z$, so long as $Y$ has relative autonomy. This conclusion is distinct from the majority view which holds that, when $\mathrm{X}$ coerces $\mathrm{Y}$ into consenting to $\mathrm{Z} \varphi$-ing, $\mathrm{Z}$ acts impermissibly in $\varphi$-ing or acts permissibly if $\varphi$-ing increases $Y^{\prime}$ 's options, helps $Y$ avoid harm, or is the only method of $\mathrm{Y}$ avoiding the fulfilment of $\mathrm{X}^{\prime} \mathrm{s}$ threat.

\subsection{Responsibility}

There is a related second objection. Some claim that valid consent increases one's responsibility, either in terms of increasing the extent that one's actions can be attributable to oneself, or in terms of increasing the extent that one's actions can be viewed as a reason to blame or praise oneself. ${ }^{24}$ For example, validly consenting to give away money means that one is responsible for the loss of one's money, in both the sense that the loss of one's money is attributable to oneself and that there is reason to blame or praise oneself for the loss of this money. If one is coerced by a third party into giving away one's money, it seems one does not increase one's responsibility for the loss of one's money. It seems David similarly never increased his responsibility for his movement across the border given that he consented to cross due to government coercion.

One response is to reject the premise that individuals may not increase their responsibility when consenting due to wrongful coercion from a third party. It seems such individuals only fail to increase their responsibility if they lack relative autonomy. For example, if Ashoul offers only passage to Ethiopia, despite having a duty to also offer passage to Australia, harm befalling David in Ethiopia appears to be 
the responsibility not of David, but of both the government and Ashoul. If Ashoul has no duty to provide passage to Australia however, and genuinely provides all options she has a duty to provide, it seems her responsibility is decreased, while David's is increased, even if the government's responsibility remains unchanged. In this second case, Ashoul can legitimately say, "I am sorry you are suffering, but the choice to cross into Ethiopia was yours at least as much as mine: you are therefore at least partially responsible for what happened to you, given the consent you gave." This contrasts with the first case where David can reasonably hold Ashoul's failure to fulfil her duties towards him as causally contributing to his harm, such that she bears greater responsibility and he less.

Even if one rejects the claim that David increased his responsibility in a manner that meant he gave valid consent, this still leaves open the substantive question of what implications this has for Ashoul, the consent-seeker. While in cases of two-party wrongful coercion it seems the consent-seeker acts impermissibly and takes on some or all of the blame for the consent-giver's choices - a mugger acts wrongly and is blameworthy for the victim's loss of money - it is not clear if this holds for cases of third-party coercion. ${ }^{25}$ A responsibility-based theory which accounted for consentseekers in cases of third-party coercion would establish not only the consent-giver's responsibility, but when a loss of responsibility for the consent-giver places responsibility on the consent-seeker, or makes her actions impermissible. The theory of relative autonomy provides one potential answer: if a consent-giver has relative autonomy vis-à-vis the consent-seeker, then by consenting he cannot place responsibility on the consent-seeker, and the consent-seeker acts permissibly. For example, David cannot hold Ashoul responsible for crossing into Ethiopia, or blame her, or claim she committed a wrong. If so, then regardless of whether we claim he gave "valid consent," it seems that the more substantive claim remains: consent given due to third-party coercion grants permission to the consent-seeker if the consentgiver has relative autonomy from the consent-seeker.

\subsection{Reasonableness}


The third objection is against this more substantive claim. According to some, when one is coerced into consenting by a third party, then:

(a) her consent is invalid when resulting from a lack of autonomy she has a right to obtain from all agents and

(b) her invalid consent can still give permission to the consent-seeker if both she and the consent-seeker take "the viewpoint of the other as seriously as her own and deciding on this basis what to do".

(c) They can do this if both act according to what is reasonable for both to pursue. ${ }^{26}$

For example, David's consent gives Ashoul permission to help him cross the border if she takes his viewpoint seriously in deciding what to do. She does so if she recognizes that remaining in his home country is not a reasonable option for him, and that being carried across the border is. Carrying him across the border at very little cost is also a reasonable option for her. Therefore, the only option that is reasonable for both is carrying him across the border. This - according to the competing theory - explains why it is permissible for Ashoul to carry him across the border, while maintaining that his consent is invalid: it is invalid because he lacks the autonomy he has a right to receive from the government.

There are reasons to reject both (c) - the theory's criteria for permissibility - and (a) the claim that consent is never valid when an agent lacks the autonomy to which they have a right to obtain from all agents.

A reason to reject (c) is that it fails to account for cases where no option is reasonable for both agents. Imagine that Ashoul would place her own life at risk in carrying him across the border, because she would need to cross unsafe armed territory. It would be unreasonable for her to help, in addition to being unreasonable for David to remain in his country. Though neither option would be reasonable for both, Ashoul can still obtain David's permission to assist him. Importantly, she acts permissibly not because 
repatriation is reasonable for David, since the act would remain impermissible if repatriation were reasonable and he declined, but because repatriation is his choice.

The proposed theory captures the value of this choice, and also explains why it constitutes a form of valid consent. One's choice has value not because it is a joint decision which is reasonable for both agents, but because the agent giving consent has the autonomy he has a right to receive from the consent-seeker. In ensuring such autonomy, the consent-seeker helps the consent-giver gain control over the permission granted.

This leaves open the possibility of a revised version of the competing theory, where (a) and (b) remain but (c) is modified to: "They can take the viewpoint of the other as seriously as her own in deciding what to do if both provide the other as much autonomy as they have a duty to provide."

This modification clarifies that permission can be granted with relative autonomy, and so maintains this article's more substantive claim, but maintains the less-substantive competing view that permission is distinct from valid consent. Some might feel it is important to maintain this less-substantive claim because of a final objection.

\subsection{Ordinary language}

The final objection is that referring to permission given with relative autonomy as "valid consent" is contrary to ordinary linguistic usage, which can lead to misunderstanding. For example, imagine David had a gun pointed to his head by an assailant who would definitely pull the trigger unless Ashoul brought him across the border. He could have relative autonomy and so give permission, but claiming David gave valid consent might lead some to believe he was not coerced. ${ }^{27}$ This is one reason to avoid the term "valid consent" to refer to consent given with third-party coercion. Using the term in this way entails revising language, incurring risks of misunderstanding which we ought not incur. ${ }^{28}$ 
While the theory of relative autonomy certainly requires that we revise our language, and we incur risks in doing so, there are also major benefits. By claiming one can give valid consent to a consent-seeker who ensures relative autonomy, we make clear they never gave valid consent to others. David never gave valid consent to the government for his departure because the government failed to ensure he had the autonomy it had a duty to provide.

Importantly, we can claim that one's consent was invalid for all those who issued wrongful threats. This might include members of society who engaged in their own forms of wrongful coercion or denial of options. For example, members of the public might discriminate, engage in violence, or use derogatory language against David because he is Darfuri. These acts constitute threats of further harm unless he leaves the country. By stating that David gave valid consent only to Ashoul, while clarifying he was threatened by others, we shift our gaze from Ashoul to these others. This emphasizes the distinct ways that different parties fail to protect autonomy, and the distinct wrongs they commit. This nuance is missing in today's language of valid consent, which views consent as either valid or not, rather than valid for particular agents.

This nuance extends to distinguishing between individuals and the groups they are members of. Sometimes individuals obtain valid consent while groups they are members of do not. For example, imagine that David's government was only persecuting him so he would leave, and would cease persecution if no aid worker helped him leave. In such cases, all aid workers helping him leave would be collectively necessary for the government's persecution. They could enhance his autonomy by refusing to help him escape. These aid workers might therefore have a collective duty to better protect David's autonomy by refusing to help him leave the country, and so would fail to collectively obtain his valid consent to leave the country. It is nonetheless true that a given aid worker, who knows other aid workers will continue to help him leave regardless of her actions, does not contribute to government coercion as an individual. She can obtain David's valid consent because 
she provides as much autonomy as she can individually, even if aid workers collectively do not. In other words, if groups can have duties which their members do not have, groups can fail to obtain valid consent even if their members do. The theory of relative autonomy captures this distinction.

Importantly, the theory is consistent with the language used in other consent scenarios where autonomy is undermined. Within medicine, we do not demand that doctors ensure patients have as much autonomy as they have a right to obtain from all other agents; only as much as they have a right to obtain from the doctors themselves. For example, if a person is shot by a sniper and accepts life-saving treatment from a doctor, the sniper wrongly reduces her autonomy by denying her the option of living without the wound; nevertheless, she may give valid consent to the doctor. We use this language of valid consent to signify that she has given permission to the doctor, not the sniper, emphasizing which party has violated their duties and which has not.

More generally, the focus on relative autonomy is consistent with how we approach other conditions for valid consent. We tend to think valid consent requires a certain level of mental capacity, but few claim consent requires the capacity to which one has a right. A patient might lack the capacity to understand what a treatment entails, because as a child she faced abuse which impacted her cognition, but she can give valid consent to a doctor who maximises her capacity. ${ }^{29}$ Similarly, few claim the consent-giver must have information they have a right to obtain from all agents. ${ }^{30}$ Sometimes a patient cannot access information on risks, because the government wrongly failed to conduct clinical trials to determine risks. He lacks the information he has a right to obtain from the government, but if the doctor discloses the information she is able to obtain, she can obtain the patient's valid consent.

3. Third-party coercion as insufficient to invalidate consent One claim defended in the two preceding sections is that relative autonomy is sufficient for valid consent under conditions of third-party coercion. This section 
demonstrates that, when consent is invalid under third-party coercion, the coercion is insufficient by itself to invalidate the consent.

To see how, consider a case of invalid consent with third-party coercion, where $X$ threatens to harm $Y$ unless $Z$ either $\varphi$-es or $\varphi^{*}$-es, and $Z$ knowingly has a duty towards $Y$ to offer to $\varphi^{*}$, but knowingly only offers to $\varphi$. Such was possibly the case with Aminata in 1990s Sierra Leone. Below is a fuller description of this case:

Coerced Sex: Aminata is threatened with rape by an RUF soldier unless she marries and has sex with Ousman. However, this is not quite true: if she merely marries Ousman, and they secretly do not have sex, then the soldier will not rape her. Ousman is aware of the RUF soldier's threat and could easily marry her and refrain from sex. ${ }^{31}$ He instead only offers marriage on the condition that they have sex.

In the case above, and other cases from 1990s Sierra Leone, men's offers of marriage did not increase women's chances of facing threats of rape from soldiers. It was just that women accepting marriage decreased their chances of being raped by soldiers. Though Ousman did not causally contribute to the threats of rape in this way, he may have had a duty to offer a sexless marriage if this entailed negligible costs, ${ }^{32}$ because we have a duty to help others avoid serious harm if this involves only negligible costs. ${ }^{33}$ Or he might have had no duty to offer marriage at all, as the costs would be high, but if offering marriage he would have a duty to include the offer of a sexless marriage: only offering marriage-with-sex might be impermissibly exploitative, especially if he sought out coerced women with the goal of obtaining coerced sex. ${ }^{34}$ If Ousman had a duty to offer Aminata a sexless marriage, and instead only offered marriage-with-sex, he failed to provide her the autonomy he had a duty to provide. He therefore failed to obtain her valid consent.

This demonstrates that third-party coercion is insufficient to invalidate consent. If Aminata lacks valid consent partly because of Ousman's failures to ensure a given level of autonomy, then her consent is invalid because of both the third party (the RUF soldier) and the failures of the consent-seeker (Ousman). 
The above claim might seem uninteresting: when we claim that coercion from a third party is sufficient to invalidate consent, we mean that only the third party must engage in coercion for the consent to be invalid. It seems the RUF soldier alone engages in coercion, and Ousman does not. If the RUF soldier alone engages in coercion, but Ousman still fails to obtain valid consent, it seems that agents can fail to obtain valid consent despite engaging in no coercion themselves.

I think this is incorrect, at least in cases where the consent-seeker is fully aware of the threat from the third party. When the consent-seeker is fully aware of the threat from the third party, and fails to protect the consent-giver's relative autonomy, the consentseeker does engage in wrongful coercion himself.

To see why, consider what we mean when claiming an agent engages in coercion. An agent $\mathrm{X}$ engages in coercion against $\mathrm{Y}$ when three jointly sufficient conditions are met:
a) X threatens to seriously harm $Y$ unless $Y \varphi$-es,
b) $X$ has a duty to not harm $Y$ even if she does not $\varphi$, and
c) Y $\varphi$-es to avoid X's harm. ${ }^{35}$

For these conditions to be met, the coercer needn't explicitly threaten the coerced; it can be enough that he implies a threat. For example, if it were widely known that a man beats up women who fail to have sex with him, and both the man and a given woman know she is only having sex for this reason, the man would coerce this woman into having sex.

There is a related set of jointly sufficient conditions for $\mathrm{X}$ to coerce $\mathrm{Y}$ :

a) $X$ threatens to let $Y$ face serious harm unless $Y \varphi$-es,

b) $X$ has a duty to not let $Y$ face harm even if $Y$ does not $\varphi$, and

c) Y $\varphi$-es to avoid $X$ letting her face harm. 
For example, if a doctor

(a) has life-saving medicine that he has a duty to provide a given woman, and

(b) threatens to let her die without the medicine unless she has sex, and

(c) she has sex in order to obtain this medicine

then the doctor coerces her into having sex. ${ }^{36}$

Here, too, an implied threat is sufficient. If both she and the doctor know he will not provide the medicine unless she has sex, and she has sex as a result, then she is coerced into having sex, regardless of whether the threat is made explicit.

Even conditional duties can imply a threat like the one above, though of a slightly different variety. Imagine that a doctor has no duty to offer medicine at all, but if he offers medicine, he has a duty to offer medicine for free. It follows that denying medicine is permissible and only offering medicine for sex is impermissible. If denying medicine is permissible, and he threatens to deny her medicine unless she has sex, he is not threatening to do something impermissible. He is instead threatening to do something permissible (denial of medicine) unless she accepts his impermissible offer (medicine for sex). If his threat has an impermissible element - the offer of medicine for sex - then he acts wrongly in engaging in the threat. Of course, this raises the question of whether and why one acts wrongly in threatening to do what is permissible to do. But if one holds that one can act wrongly when threatening to do a permissible act ${ }^{37}$ then agents like the doctor are engaging in a wrongful threat.

When Ousman only offers marriage with sex, knowing that Aminata is facing the RUF soldier's threat, he is implying the following: "If you do not have sex with me within a marriage I will let you be raped by the RUF soldier." If Ousman has a duty to marry her without sex, the three jointly sufficient conditions are met: 
(a) Ousman threatens to let Aminata face serious harm unless she has sex,

(b) Ousman has a duty to not let her face harm even if she does not have sex, and

(c) Aminata has sex in order to avoid Ousman letting her face harm.

If this type of implied threat is sufficient for coercion, then Ousman coerces Aminata into sex. Moreover, he coerces her even if his duty is conditional. If he normally has no duty to marry her, but a duty to offer sexless marriage if he does offer marriage, he violates his duties towards her when only offering marriage-with-sex. In doing so, he wrongfully threatens her with a permissible act (no marriage) that would lead to harm from a third party, unless she accepts an option (marriage-with-sex) that is impermissible without a corresponding offer (sexless marriage). Because his threat has an impermissible element - the offer of marriage-with-sex without an offer of sexless marriage - he acts wrongly in engaging in the threat.

The above demonstrates that, in at least this case, third-party coercion does not fully explain the invalidity of the consent: coercion from the second party is involved as well. More generally, when a consent-seeker fails to provide an option he has a duty to provide, knowing this will result in the consent-giver accepting a remaining option to avoid harm from a third party, the consent-seeker engages in coercion himself.

The same holds true for the case of David and Ashoul. If Ashoul had demanded a very high fee for her services, and this high fee was impermissible, then she would have implied an impermissible threat: "Pay me the high price or I will let you face persecution by your government." Or consider a more common type of third-party coercion, where $\mathrm{X}$ coerces $\mathrm{Y}$ into consenting the transfer of property to $\mathrm{Z}$, as when white supremacists in 1950s Chicago threatened to kill black residents unless they sold their houses to white buyers, ${ }^{38}$ or when Idi Amin threatened to detain any IndianUgandans unless they sold their property to Ugandans of African descent. ${ }^{39}$ If buyers in such cases have a duty to only temporarily take the property and return it once the coercer's threat has subsided, then those who demand a permanent transfer are implying the following impermissible threat: “Unless you give me your property 
permanently, rather than only lend it to me temporarily, I will let you face harm from the coercer."

The above claim - that invalid consent from third-party coercion entails direct coercion from the consent-seeker - may be limited to cases where the consent-seeker has full information. These are the types of cases which this article focuses on, but sometimes the consent-seeker really does lack full information about the third party's coercion. In such cases the consent-seeker cannot be said to engage in direct coercion. Consider Coerced Sex 2:

Aminata is threatened with rape by an RUF soldier unless she consents to marry Ousman and have sex with him. She consents to marry Ousman and have sex with him solely because of this threat, but does not tell Ousman about the RUF soldier's threat. Had Ousman known about the threat, he may have offered a sexless marriage, and the RUF soldier would never find out.

It seems Ousman implies no threat. Given his ignorance, he never implied, "Marry me and have sex with me, or I will let you be raped by the RUF soldier." Moreover, some might claim Ousman fails to provide the autonomy he has a duty to provide, because Ousman unknowingly is exploiting Aminata. If his failure to ensure relative autonomy means he fails to obtain her valid consent despite not engaging in coercion himself, then this is a case of invalid consent with coercion from the third-party alone.

Whether one accepts this conclusion will depend on whether one accepts that agents can have duties which they are ignorant of, on account of ignorance about facts they cannot reasonably access. If one can, Ousman fails to obtain Aminata's valid consent despite engaging in no coercion himself. He therefore commits a wrong without being aware that he is, and so without implying a threat himself.

It remains the case that, where the consent-seeker is aware of a threat, the consentseeker implies a threat himself. 


\section{A second variant of third-party coercion}

All cases so far involve $X$ harming $Y$ unless $Z$ does in fact $\varphi$, where $Y^{\prime}$ s relative autonomy validates consent despite $X^{\prime}$ s threat. We might suppose relative autonomy does not validate consent when $\mathrm{Y}$ must merely give $\mathrm{Z}$ permission to $\varphi$ to avoid X's harm, regardless of whether or not $\mathrm{Z} \varphi s$.

For example:

Coerced Sex 3: A pimp threatens to harm Charlotte, a sex worker, unless she gives the client permission to have sex with her. The pimp does not care whether the client actually has sex with her: it only matters that she gives the client permission. Charlotte tells the client that he has permission and the client does not have sex with her.

In this example, Charlotte has relative autonomy because the client is giving her every option he can provide, and no autonomy-reducing options he has a duty to not provide. He gives her the option to either give him permission or not, thus helping her avoid the pimp's harm, and does not deny her a non-exploitative offer, given that he does not have sex. Moreover, we can presume that Charlotte has the relevant mental abilities to make an autonomous choice: perhaps she has decided after careful deliberation that giving him permission is what she wants, and she might even privately form the mental state of deciding he has permission, because she fears the pimp can read her mind. If she really has decided to give permission with relative autonomy, it still seems the client does not actually have permission to have sex. If valid consent entails the successful giving of permission, he has not obtained her valid consent. In other words, third-party coercion seems to invalidate consent despite Charlotte having relative autonomy from the client, and despite the client neither engaging in coercion himself nor being ignorant about the pimp's threat.

While it may be true that the client engages in no coercion himself, and is aware of the pimp's threat, relative autonomy still explains the invalidity of Charlotte's consent. 
If Charlotte does have sex, she will be experiencing coerced sex. She would prefer to instead have the option of deciding that the client has permission without actually having sex. Assuming that not having sex would be costless for the client, he can provide her this option at negligible cost. He therefore has a duty to provide her this option. If he does not, he fails to protect her relative autonomy; this explains why he acts impermissibly, and why he fails to obtain her valid consent.

Put differently, if the client will have sex as a result of Charlotte deciding he has permission, he provides her this option set:

Option 1a. She can communicate and decide that the client has permission, after which the client will have sex and she will not face the pimp's harm or

Option $1 \mathrm{~b}$. She can communicate and decide that the client has no permission to have sex, in which case she will face the pimp's harm.

In contrast, if the client will not have sex despite Charlotte deciding he has permission, he provides her this option set:

Option 2a. She can communicate and decide that the client has permission, after which the client will not have sex and she will not face the pimp's harm or

Option $2 \mathrm{~b}$. She can communicate and decide that the client has no permission to have sex, in which case she will face the pimp's harm.

The number of options in both sets are the same, but the quality of options 1a and 2a differ. Option 1a in the first set includes her having coerced sex. In contrast, 2a entails no such sex. The client likely has a duty to provide her a set of options that includes 2a, either because doing so would presumably be costless, or because denying this option might be a form of wrongful exploitation. If he ought to provide this option, he can only ensure she has options she has a right to if he has no sex. He can therefore only ensure she has relative autonomy if he has no sex. This explains why he maintains no permission to have sex, and why her consent is invalid. 
More generally, when a consent-seeker has a duty to provide a consent-giver the option of simultaneously avoiding the fulfilment of the coercer's threat and the act coerced by the threat, and this option is mutually-exclusive with a second option of avoiding the fulfilment of the coercer's threat by fulfilling the coerced act, he ought to provide the first option and not the second. Such cases arise when $\mathrm{X}$ coerces $\mathrm{Y}$ into giving permission to $Z$ to $\varphi$, where $Z$ needn't $\varphi$, such that $Z$ not $\varphi$-ing will give $Y$ the option of avoiding $X^{\prime}$ s coercion whilst experiencing no coerced $\varphi$. If $Z$ has a duty to provide this option, and it cannot be provided if $Z \varphi$-es, then $Z$ can only protect $Y^{\prime} s$ relative autonomy by not $\varphi$-ing. Once again, relative autonomy helps explain when consent is valid and when it is not.

\section{Third-party coercion with third-party harm}

This final variant includes third-party coercion alongside "third-party harm." To explain why the theory of relative autonomy applies to such cases, it is necessary to first explain why the theory applies to third-party harm alone, without any third-party coercion. ${ }^{40}$ Such cases occur when $\mathrm{X}$ threatens to wrongly harm a third-party $\mathrm{W}$ unless $\mathrm{Y}$ consents to $\mathrm{X} \varphi$-ing. For example:

Coerced Sex 4: A pimp threatens to kill a stranger in a distant city unless Charlotte has sex with the pimp, and Charlotte consents solely because she does not want the stranger to die as a result of her inaction.

Such cases seem perplexing, as it is unclear why they involve wrongful coercion, given that the threat-giver does not threaten to harm the threat-recipient. One explanation has recently been proposed by Stephen White: the threat-giver wrongs the threatrecipient because he places a heavy responsibility on her to decide if he commits a wrong, a responsibility he ought to bear himself, given all agents ought to be responsible themselves for whether they commit wrongs. ${ }^{41}$ Even if Charlotte is not morally responsible for the stranger's death in refusing to have sex, she would still be implicated in his death, in that she would have chosen an action which she knew causally contributed to it. ${ }^{42}$ In knowing that refusing sex would contribute to this 
action, she is faced with a burden of deciding whether to avoid sex or bring about an outcome of great moral importance (the prevention of a wrongful death). To avoid placing this burden on Charlotte, the pimp must provide her the option of neither having sex nor him killing the stranger, and so denying her this option denies her relative autonomy. If she consents as a result of being denied relative autonomy, her consent is invalid.

This theory can establish when consent is invalid in cases with both third-party harm and third-party coercion, where $X$ will harm a third-party $W$ unless $Z \varphi$-es, and $Y$ consents as a result:

Coerced Sex 5: A pimp threatens to kill a stranger in a distant city unless Charlotte has sex with a client. The client is aware of the pimp's threat and could easily persuade the pimp they had sex without actually having sex, preventing the pimp from killing the stranger. He instead only offers to persuade the pimp they had sex if Charlotte actually has sex, and Charlotte consents solely because she does not want the stranger to die as a result of her inaction.

In this case the client places Charlotte in a position where refraining from sex will mean the client will not tell the pimp they had sex, causing the pimp to kill the stranger. The client therefore places Charlotte in a position where she can either have sex or causally contribute to a wrongdoing. He therefore places a weighty responsibility on her, a responsibility he could alleviate by simply lying to the pimp. If successfully lying to the pimp is costless, he has a duty to provide this option, and fails to protect Charlotte's relative autonomy if he does not, and fails to obtain her valid consent for sex.

If successfully lying to the pimp involves costs - perhaps he will need to pay the pimp some money to persuade him that they actually had sex - then the client might still have a duty to offer to successfully lie to the pimp, paying money in the process. ${ }^{43}$ If the pimp wrongs Charlotte for the reasons described above, then the client may be exploiting the wrong she faces if he has sex with her. If this is impermissible exploitation, and such exploitation can only be avoided by either not having sex or 
offering to lie for her at some expense, then he would have a conditional duty to offer to lie for her at some expense. In such circumstances, only offering sex would deny Charlotte an option to which she had a right, undermining her relative autonomy. If she consented to sex as a result, she would fail to give valid consent.

\section{Conclusion}

I began this article by describing a common claim: consent resulting from a wrongful third-party threat is necessarily invalid, and this implies that those obtaining such consent act impermissibly in pursuing the object of consent, or act permissibly only if the object of consent improves the consent-giver's options, helps her avoid harm, or is the only way to help her avoid the fulfilment of the coercer's threat. I argued that these conditions are neither necessary nor sufficient for either valid consent or granting permission. I proposed the alternative theory of relative autonomy: when a coerced agent has the autonomy the consent-seeker has a duty to provide, this is sufficient for valid consent and permission. I further argued that when the consent-giver does not give valid consent because they lack relative autonomy, and the consent-seeker is aware of the coercion the consent-giver faces, the consent-seeker engages in coercion himself; he is not a mere innocent bystander, attempting to make the best of a bad situation, but is implying a wrongful threat directly.

The above arguments demonstrated that the theory of relative autonomy explains the validity and invalidity of consent in a broad range of cases, including those not captured by competing theories. In doing so I have attempted to establish more precisely when consent resulting from third-party coercion grants permission and when it does not.

\footnotetext{
${ }^{1}$ This is a simplified case based on actual cases arising during the Sierra Leone Civil War. In actual cases, women were often raped prior to and after capture, and women marrying senior officers obtained greater protection than women marrying junior officers, soldiers, and non-soldiers. For the full complexity surrounding marriage and rape during the war, see Zoe Marks, "Sexual Violence in Sierra Leone's Civil War: 'Virgination,' Rape, and Marriage," African Affairs 113 (2013): 67-87.
} 
2 Paul S. Appelbaum, Charles W. Lidz, and Robert Klitzman, “Voluntariness of Consent to Research: A conceptual model," Hastings Center Report 39 (2009): 30-39 at 33; Rosalie Ber, "Ethical issues in gestational surrogacy," Theoretical Medicine and Bioethics 21(2000): 153-169 at 159; Michael Barnett, "UNHCR and the Ethics of Repatriation," Forced Migration Review 10(2001): 31-34; Andrea Dworkin, Intercourse, New York: Free Press/Macmillan 1987; Shannon Lydia Spruit, Ibo van de Poel, and Neelke Door, "Informed Consent in Asymmetrical Relationships: an investigation into relational factors that influence room for reflection," Nanoethics 10 (2016):123-138 at 126; Joseph Millum, "Consent Under Pressure: The puzzle of third party coercion," Ethical Theory and Moral Practice 17 (2014):113-27; Japa Pallikkathayil, "The Possibility of Choice: Three Accounts of the Problem of Coercion," Philosophers' Imprint 11 (2011): 1-20 at 14.

${ }^{3}$ See Larry Alexander, Heidi Hurd, and Peter Westen, "Consent Does not Require Communication: A reply to Dougherty," Law and Philosophy 6 (2016): 655-660 at 656-657; Tom Dougherty, "Yes Means Yes: consent as communication," Philosophy and Public Affairs 43 (2015): 224-253 at 226; Kimberly Kessler Ferzan, “Consent, Culpability and the Law of Rape," Ohio State Journal of Criminal Law 13 (2016):397439; Victor Tadros, Wrongs and Crimes, Oxford: Oxford University Press 2017 at 204-5.

${ }^{4}$ I assume that, for a consenter to successfully dissolve a duty, she must hold a particular mental state. Some claim a consent-giver must decide to give permission; others claim they must intend that the consentseeker act in some way; there are still more theories, but here it is enough to simply assume that some unspecified mental state must be held by the consent-giver. I shall also assume that the consenter-giver's consent is only valid if she communicates her consent, but my argumentation is not dependent on this claim. For various theories of the mental state necessary for consent, see Larry Alexander, "The Moral Magic of Consent (II)," Legal Theory 2 (1996): 166-174 at 166; Heidi Hurd, “The Moral Magic of Consent," Legal Theory 2 (1996): 121-46 at 131; Peter Westen, The Logic of Consent: The Diversity and Deceptiveness of Consent as a Defense to Criminal Conduct, Aldershot: Ashgate Publishing 2004, Ch. 1; Tadros, Wrongs and Crimes at 205 and 206. For a defense of the claim that consent requires communication, see Dougherty, "Yes Means Yes: consent as communication," and Richard Healey, “The Ontology of Consent: A reply to Alexander," Analytic Philosophy 56 (2015): 354-363 at 358-260.

${ }^{5}$ More accurately, the consent dissolves her partner's moral duty towards her to not have sex with her. Her partner might still have a duty towards others to not have sex with her. For example, her partner might have a duty to perform life-saving surgery at the moment he is having sex, and so a duty at that moment to not have sex. He still has no duty towards her to not have sex.

${ }^{6}$ By "function" I mean the effect and the value promoted in having this effect. For example, some might claim that the function of a car is to bring individuals from one location to another in a manner that promotes the value of mobility. The function of consent is to dissolve a duty in a manner that promotes the value of having autonomous control. For brevity, I simply claim throughout that the function of consent is to protect individuals' autonomy.

7 Larry Alexander, “The Ontology of Consent," Analytic Philosophy 55 (2014): 102-113 at 108; Ferzan, "Consent, Culpability and the Law of Rape," at 405-406; Tadros, Wrongs and Crimes at 207.

${ }^{8}$ Ezekial J. Emmanuel, David Wendler, Jack Killen, and Christine Grady, “What Makes Clinical Research in Developing Countries Ethical?" JID 189(2004):930-938 at 935; Ezekial J. Emmanuel, David Wendler and Christine Grady, “What Makes Clinical Research Ethical?” JAMA 283(20)(2000):2701-2711; Jeff Crisp and Katy Long, "Safe and Voluntary Refugee Repatriation: From principle to practice," Journal on Migration and Human Security 4(3)(2016):141-147 at 146.

${ }^{9}$ Wertheimer and Miller hold that consent resulting from third-party coercion can create a permission to avoiding depriving the coerced party "of the opportunity to improve her condition by transacting with" the consent-seeker. See Franklin Miller and Alan Wertheimer, "A Preface to a Theory of Consent Transactions: Beyond valid consent," in The Ethics of Consent: theory and practice, eds. F. Miller \& A Wertheimer (Oxford: Oxford University Press, 2009), at 98. Wilkins addresses organ purchases, arguing they are permissible even if consent is the result of third-party coercion and thus invalid. He claims that, "insisting on [valid consent] where this will be clearly harmful and option-constraining would be perverse." This seems to imply that if consent is invalid for a given action, the action could still be permissible if this helps the coerced consent-giver and increases their optionality. See Stephen Wilkinson, "Exploitation in International Paid Surrogacy Arrangements," Journal of Applied Philosophy 33 (2016): 125-145 at 138. For similar claims in other contexts, see Megan Bradley, Refugee Repatriation: Justice, Responsibility, Redress, Cambridge: Cambridge University Press 2014 at 52; Ruth Faden and Tom 
Beauchamp, A History and Theory of Informed Consent (New York: Oxford University Press, 1986) at 279 and 346; For similar claims in other contexts, see Ber, "Ethical issues in gestational surrogacy," at 166-167; Jill A. Fisher, "Expanding the Frame of 'Voluntariness' in Informed Consent: Structural Coercion and the Power of Social and Economic Context," Kennedy Institute of Ethics Journal 23 (2013): 355-379 at 368; Janet Radcliffe Richards, "Consent with Inducements: The case of body parts and services," in The Ethics of Consent: theory and practice, eds. F. Miller \& A Wertheimer, (Oxford: Oxford University Press, 2009), 281-304 at 294. Some imply that consent resulting from third-party coercion can generate a permission if this helps others, even if not the individual doing the consenting. See Heidi Hurd, "The Normative Force of Consent," in The Routledge Handbook on the Ethics of Consent, eds. Peter Schaber and Andreas Muller (Abingdon and New York: Routledge, 2018) at 19.

${ }^{10}$ Dougherty seems to present this as a sufficient condition, though not a necessary condition. He claims consent gives permission when $Z$ "can do no better to respect" $Y$ 's agency than by offering $\varphi$, and this occurs when $\varphi$ is the only way that $Z$ can stop the fulfilment of $X^{\prime}$ s threat. See Tom Dougherty, "Why Does Duress Undermine Consent?" Nous (forthcoming), at 11 in pre-publication manuscript. https://onlinelibrary.wiley.com/doi/abs/10.1111/nous.12313

${ }^{11}$ Here $\mathrm{Z}$ and $\varphi$ represent sets of possible actors and actions that may neutralize the threat posed by $\mathrm{X}$. For example, the government might threaten to harm David unless he leaves for Ethiopia or Egypt, and he can only leave via Ashoul or pay for a smuggler. Leaving for either country is a distinct action occurring in the set of possible actions that neutralize the threat posed by the government. Ashoul and a smuggler are each members of the set of actors capable of performing one of these neutralizing actions. Note that, under this understanding of third-party coercion, $X$ is not necessarily aware of $Z$ 's existence; it is simply that $X$ will harm $Y$ unless $Z$ acts a particular way.

${ }^{12}$ This needn't mean that $Y$ would not have consented had it not been for $X^{\prime}$ s threat. It may be that $X^{\prime}$ s threat contributes to Y's consent in a non-counterfactual sense. See Victor Tadros, "Consent to Sex in an Unjust World," this issue.

${ }^{13}$ For our purposes, $\mathrm{Z}$ is not causally contributing to $\mathrm{X}^{\prime} \mathrm{s}$ coercion if she is not increasing the probability of $X^{\prime}$ 's coercion, is not necessary for $X^{\prime}$ s coercion, and would not be necessary for $X^{\prime}$ s coercion in any nearby possible world. For more on this condition, see Mollie Gerver, "Refugee Repatriation and the Problem of Consent," British Journal of Political Science 48 (2018): 855-875 at 864-867.

${ }^{14}$ Personal interview with David, Addis Ababa, 12 June 2014.

${ }^{15}$ Alexander, “The Moral Magic of Consent (II)," at 172; Alexander, “The Ontology of Consent," at 108; Alexander, Hurd, and Westen, "Consent Does not Require Communication: A reply to Dougherty"; Dougherty, "Yes Means Yes: consent as communication"; Mark Dsouza, "Undermining Prima Facie Consent in the Criminal Law," Law and Philosophy 33 (2014): 489-524 at 493 and 501-502; Healey, "The Ontology of Consent: A reply to Alexander"; Hurd, "The Normative Force of Consent"; Hurd, "The Moral Magic of Consent"; Ferzan, "Consent, Culpability and the Law of Rape," at 405-406; Tadros, Wrongs and Crimes at 207.

${ }^{16}$ Ber, "Ethical issues in gestational surrogacy," at 159; Dsouza, "Undermining Prima Facie Consent in the Criminal Law," at 508-511; Faden and Beauchamp, A History and Theory of Informed Consent at 81; Quarraisha Abdool Karim, Salim S. Abdool Karim, Hoosen M. Coovadia, MBBS, and Mervyn Susser, "Informed Consent for HIV Testing in a South African Hospital: Is It Truly Informed and Truly Voluntary?" Public Health Briefs 88 (1998): 637-640; Millum, "Consent Under Pressure: The puzzle of third party coercion," at 115; Pallikkathayil, "The Possibility of Choice: Three Accounts of the Problem of Coercion," at 2 and 14; Stephen Wilkinson, Bodies for Sale: Ethics and Exploitation in the Human Body Trade (London: Routledge, 2003) at 170.

17 This is consistent with the view that some options do not increase autonomy, and that there are some number and quality of options that render a person completely autonomous, where no extra number or higher quality would contribute to greater autonomy. See Paul Hughes, "Exploitation, Autonomy and the Case for Organ Sales," International Journal of Applied Philosophy 12(1)(1998):89-95 at 92; Liam Shields, Just Enough: Sufficiency as a demand of justice, (Edinburgh: Edinburgh University Press, 2016), ch. 3; James Stacey Taylor, "Autonomy, Constraining Options, and Organ Sales," Journal of Applied Philosophy 19 (2002): 273-285. It is worth noting that autonomy likely requires certain mental conditions, such as the capacity to think through one's decisions, and reflect on one's options. I assume, for the purposes of this article, that the relevant mental conditions for autonomous decision-making are met in all of the cases I discuss. This is because proponents of the view that third-party coercion invalidates 
consent never claim that consent is undermined as a result of coercion undermining mental capacity. They instead claim that consent is undermined because it constrains a person's options due to the wrongful coercion they face. That said, it may be true that third-party coercion can invalidate consent by invalidating the mental capacity of the consent-giver. This is a possibility raised by Liberto in Hallie Liberto, "Coercion, Consent and Moral Debilitation," (this issue).

${ }^{18}$ David would have had no options if Ashoul had picked up him despite his desire to remain, and handcuffed him to a seat on a bus as he was driven across a border.

${ }^{19}$ Relative autonomy is far narrower than what has been called "relational autonomy." The latter refers to the autonomy held in virtue of certain social relations in general, including relations which enhance certain mental capacities and senses of self-worth. For more on relational autonomy, see Catriona Mackenzie, "The Importance of Relational Autonomy and Capabilities for an Ethics of Vulnerability," in Vulnerability: New Essays in Ethics and Feminist Philosophy, eds. Catriona Mackenzie, Wendy Rogers and Susan Dodds, (Oxford: Oxford University Press, 2013).

${ }^{20}$ For views that hold we can have duties to not exploit even when we have no duty to help at all, see Robert Goodin, Protecting the Vulnerable (Chicago: University Of Chicago Press, 1986); John Roemer, A General Theory of Exploitation and Class (Cambridge, MA: Harvard University Press, 1982); Ruth Sample, Exploitation: What it is and why it's wrong (Boulder: Rowman and Littlefield, 2003); Mikhail Valdman, "A Theory of Wrongful Exploitation," Philosophers' Imprint 9 (2009): 1-14.

${ }^{21}$ Alexander, "The Moral Magic of Consent (II)"; Alexander, "The Ontology of Consent"; Dougherty, "Yes Means Yes: consent as communication"; Healey 2015 ibid; Hurd, "The Moral Magic of Consent"; Ferzan, "Consent, Culpability and the Law of Rape," at 16; Tadros, Wrongs and Crimes at 204; Westen 2016 ibid.

${ }^{22}$ In this scenario, for David to have relative autonomy he must have access to information on risks that Ashoul has a duty to disclose, as only then will he be given all options - including the options to be told about risks - which Ashoul has a duty to provide.

${ }^{23}$ Pallikkathayil, "The Possibility of Choice: Three Accounts of the Problem of Coercion," at 14.

24 The claim that consent creates a responsibility was initially proposed by Heidi Hurd, though Larry Alexander raises the similar claim that consent dissolves the right to complain, on account of taking on responsibility for the act consented to. Berman claims that the normative effect of coercion is reduced responsibility, though never claims that the function of consent is increased responsibility. Only Pallikkathayil explicitly claims both that valid consent increases responsibility and that consent is invalid if the result of coercion from a third party. See Alexander 1996 ibid at 166, Berman 2002 ibid; Hurd, "The Moral Magic of Consent" and Hurd, "The Normative Force of Consent," at Section 1A; Pallikkathayil, "The Possibility of Choice: Three Accounts of the Problem of Coercion," at 2 and 14.

${ }^{25}$ Pallikkathayil acknowledges that consent can be invalid for parties who are not responsible for the constraining of options, as in cases of third-party coercion (p. 14), and that in cases of two-party coercion the coercer is responsible (in the sense of blameworthy) for the object of consent, (p. 16), but is silent as to whether and when third-parties are responsible (as in blameworthy) for the object of consent in cases of third-party coercion. If $X$ threatens to kill $Y$ unless she hands over money to $Z$, it is not clear if and when $\mathrm{Z}$ is blameworthy for Y's loss of money. See Pallikkathayil, "The Possibility of Choice: Three Accounts of the Problem of Coercion," at 16.

${ }^{26}$ Millum, "Consent Under Pressure: The puzzle of third party coercion," at 113 and 121. Miller and Wertheimer argue that coerced consent can give permission if the recipient is treated fairly. However, they do not specify when a recipient is treated fairly. Millum's theory is the most specific answer to this question. See Franklin Miller and Alan Wertheimer, "A Preface to a Theory of Consent Transactions: Beyond valid consent," in The Ethics of Consent: theory and practice, eds. Franklin Miller and Alan Wertheimer (Oxford: Oxford University Press 2009) at 94.

${ }^{27}$ Though the theory I present implies that individuals can give valid consent even with only very poor options, they cannot give valid consent if they have no options. With no options, they have no ability at all to dissolve another's duty, and consent's purpose is to give agents the ability to dissolve another agent's duty. Two-party coercion can involve no options at all, as when a police officer imprisons a criminal, giving him no options with regards to whether he is imprisoned. The officer may be giving him all the options to which he has a right, assuming he has no right to be free, but he has not given his valid consent because he is not given the ability to dissolve a duty; there is no duty for him to dissolve if the officer maintains a duty to refrain from arresting him regardless of his consent. Put another way: he lacks the control to dissolve a duty because he has no moral right to dissolve officer's the duty to not be 
detained. It remains the case that, when the consent-seeker has a duty to not $\varphi$, she can obtain the consentgiver's valid consent to $\varphi$ even if she only offers to $\varphi$ or not to $\varphi$. Such is the case with third-party coercion, where the consent-seeker offers to perform an act which prevents the fulfilment of the third party's threat, giving the consenter the option of either giving permission for this act or not. When Ashoul offers to help David leave the country, she gives him the option of either giving her permission to carry him over the border or not.

${ }^{28}$ This objection was inspired by a helpful comment from Katy Wells.

${ }^{29}$ For a similar argument relating to capacity, see Alan Wertheimer, "Intoxicated Consent to Sexual Relations," Law and Philosophy 20 (2001): 373-401 at 389-390.

${ }^{30}$ For example, it is often claimed that the patient should be informed about known information. This is different than the claim that the patient must have access to all information to which they have a right. See Onora O'Neill, “Some Limits of Informed Consent," Journal of Medical Ethics 29 (2003) :4-7; William A. Silverman, "The Myth of Informed Consent: in daily practice and in clinical trials," Journal of Medical Ethics 15 (1989): 5-11; Tom Dougherty, "Informed Consent, Disclosure, and Understanding," Philosophy and Public Affairs 48 (2020): 119-150 at 127-128.

31 This would not involve sacrificing marriage with sex in general, as he could always enter a sexual marriage with another woman, given that polygamy is practiced in his village.

${ }^{32}$ Costs might be negligible if he could enter a sexless marriage with her but still enter a sexual marriage with another woman, possible in a culture with polygamy.

${ }^{33} \mathrm{He}$ may have a duty of rescue, or a good Samaritan duty to help her. For more on the duty to rescue and the good Samaritan duty, see Christian Barry and Gerhard Øverland, "How Much for the Child?" Ethical Theory and Moral Practice 16(1):189-204; Cecile Fabre, Whose Body Is it Anyway? Justice and the integrity of the person, Oxford: Oxford University Press 2006, ch. 1 and 2; Peter Singer, "Famine, Affluence, and Morality," Philosophy and Public Affairs 1(3)(1972):229-243.

${ }^{34}$ As noted above, see Goodin, Protecting the Vulnerable; Roemer, A General Theory of Exploitation and Class; Sample, Exploitation: What it is and why it's wrong; Valdman, "A Theory of Wrongful Exploitation." He might also have a duty to not have sex with the intention of taking advantage of her predicament. For a similar claim concerning intentions, see Tadros, "Consent to Sex in an Unjust World," (this issue).

${ }^{35}$ Some claim that close variations of these conditions are sufficient and necessary for coercion. I adopt the less-controversial claim that they are sufficient. See Mitchell Berman, "The Normative Function of Coercion Claims," Legal Theory 8 (2002): 45-89; Jennifer Greene, “Coercion: description or evaluation?" International Journal of Applied Philosophy 10 (1996): 7-16 at 12-14; Andrew Hetherington, "The Real Distinction Between Threats and Offers," Social Theory and Practice 25 (1999): 211-242 at 214-215; James R. Shaw, "The Morality of Blackmail," Philosophy and Public Affairs 40 (2012): 165-196 at 168; Alan Wertheimer, Coercion (Princeton: Princeton University Press, 1987) ch. 12; Matt Zwolinsky, "Sweatshops, Choice, and Exploitation," Business Ethics Quarterly 17 (2007): 689-727.

${ }^{36}$ This is similar to what Wilkinson calls "coercive omissions" and is integrated into Wertheimer's view on coercion. See Wertheimer 1987 ibid at 204 and Wilkinson, Bodies for Sale: Ethics and Exploitation in the Human Body Trade at 92.

${ }^{37}$ Benjamin Ferguson, “The Paradox of Exploitation," Erkenn 81 (2016): 951-972; Tadros, Wrongs and Crimes at 229. It may also be that, once the doctor is willing to give medicine for sex, he has a duty to give medicine for free. See Joe Horton, “The All or Nothing Problem," The Journal of Philosophy 114 (2017): 94-104.

${ }^{38}$ Isabel Wilkerson, The Warmth of Other Suns (New York: Vintage Books 2010) at 397.

${ }^{39}$ Nina Lakhani in "After the Exodus: 40 Years on from Amin's terror offensive against Asians in

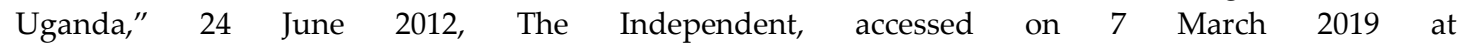
https:/www.independent.co.uk/news/world/africa/after-the-exodus-40-years-on-from-amins-terroroffensive-against-asians-in-uganda-7869878.html.

${ }^{40}$ For an alternative theory of valid consent which also accounts for cases of third-party harm, see Liberto, "Coercion, Consent and Moral Debilitation."

${ }^{41}$ Stephen White, “On the Moral Objection to Coercion," Philosophy and Public Affairs 45(3)(2017):199231.

${ }^{42}$ In cases where the threat-recipient is morally obligated to acquiesce to the threat-giver's demands, then an even greater wrong is imposed on the threat-recipient. See Saba Bazargan, "Moral Coercion," Philosopher's Imprint 14(11)(2014):1-18 at 9-10

${ }^{43}$ At least, he would have a duty to pay up until a given threshold of costs. 